\title{
Japan budget threat sparks backlash
}

\section{科学技術予算削減に激しい抗議の声}

David Cyranoski

Nature Vol. 462(557)/3 December 2009

日本の科学者が、新政権の予算削減方針 に対する国内外の猛烈な抗議の声を結集 させている。

いわゆる事業仕分けは、政府に任命さ れた行政刷新会議ワーキンググループが、 多くの大型研究事業を含む約 220 件の政 府支出事業に対する予算の削減を提言す る作業だ。各グループは約 20 人のメン バーで執り行われているが、特に批判の
対象になっているのは、その中に科学者 がほとんど含まれていないことだ。ワーキ ンググループの提言は、来年度予算を 3 兆円削減する政府の取り組みの一環として 進められている。

予算削減が提言された事業には、大型 放射光施設 SPring-8（兵庫県佐用町）や 世界最速のスーパーコンピューター開発 事業が含まれている。しかし提言は、そ
れにとどまらず、多くの科学者の命綱であ る研究補助金の減額にまで及んだ（前掲 の11月19日号の記事参照)。

11 月 25 日、東京大学で「ノーベル賞. フィールズ賞受賞者による事業仕分けに 対する緊急声明と科学技術予算をめぐる 緊急討論会」が開催され、出席した 4 人 のノーベル賞受賞者と 1 人のフィールズ 賞受賞者は、約 1000 人の参加者を前に、 
予算削減によって受けるダメージについて 語った。緊急討論会の終わりでは、客席 から大きな拍手が沸き起こり、「大学予算 と研究補助金の配分を決める際に学術と 科学技術の専門家の意見を取り入れるこ と」を政府に求めるという著名な科学者 たちが作成した声明に対して、賛同の意 思が示された。

日本の科学政策の世界は、普段はもの 静かで落ち着いたところなのだが、この 1 週間、こうした緊急声明が相次いで発表 された。11月 24 日には日本のトップク ラスの国立、私立の 9 大学の学長が集まっ て、政府の方針は「世界の潮流とまさに 逆行する」とし、若手研究者に対する研 究補助金と大学運営費関連予算の維持を 求める声明を発表した。

11 月 25 日には、コンピューターや情 報技術を専門とする 9 大学の関連研究機 関の長が、存続の危機に瀕したスーパー コンピューター開発事業への支援を求め る声明を発表した。東京大学では、17 あ るグローバル COE 拠点のリーダーが署名 した、予算確保に関する要望書が、東京 大学総長名で発表された。それに加えて、 日本のトップクラスの国立、私立 9 大学 の学長とさまざまなグローバル COE 拠点 のリーダー 31 人も声明を発表した。

東京大学での緊急討論会を組織した同 大学の石井紫郎名誉教授 (法学) は、こ の突然の抗議の高まりが、日本史上で最 も騒然とした時期の 1 つだった 1960 年
安保闘争を思い起こさせると話す。当時 は、日米安全保障条約の改定に反対する 教員と学生が激しい抗議運動を展開した。

討論会翌日の 11 月 26 日には、4人 のノーベル賞受賞者（化学者の野依良治 博士、免疫学者の利根川進博士、物理学 者の江崎玲於奈博士と小林誠博士）と科 学者の代表団が鳩山由紀夫首相と会談し、 科学技術予算削減の見直しを求めた。会 談後、野依博士はNatureに対し、「会談 の席で、スーパーコンピューター、加速器、 バイオリソースといった世界的なインフラ ストラクチャーは、学界にとっても産業界 にとっても、最高水準の科学技術研究を 行ううえで絶対に必要だと指摘しました」 と語った。

この会談で、日本在住の 8 人のノーベ ル賞受賞者全員が署名した要望書が鳩 山首相に手渡された。要望書では、「資 源の乏しいわが国にとって、科学技術の 脆弱化は国家の衰退を意味する」と指摘 している。これに対し、鳩山首相は、「サ イエンスを強く支援していきます。ノーベ ル賞受賞者の意見を参考に、今後の方向 を考えたいと思います」と答えた。

事業仕分けは11月27日に終了したが、 最後の数日間にワーキンググループは、 国際的な ITER 核融合プロジェクトの一環 として計画されている、日欧協力による熱 核融合実験炉について予算要求を全額認 めた。これは、新エネルギー源とグリーン テクノロジーの開発に積極的な鳩山政権

著作権等の理由により画像を掲載することができません。

の方針と合致している。

一方、宇宙航空研究開発機構を含む」 ンソーシアムが開発中の中型ロケットにつ いては、予算計上の見送りという評価結 果となった。また既に、ニュートリノ観測 所「スーパーカミオカンデ」(岐阜県飛騨 市)、マウナケア天文台（米国ハワイ州） に設置された国立天文台のすばる望遠鏡 をはじめとする、主要な大学関連研究所 の総額約 970 億円の予算についても縮減 が提言されている。ただし、その額は明 示されていない。

東京大学数物連携宇宙研究機構の村山 斉機構長は、特に、海外の研究仲間から の支援を積極的によびかけてきた。「全世 界の著名な科学者に、文部科学省副大臣 宛てにEメールを送るよう要請してきまし た。現在私の知るかぎりでは、約 100 人 の科学者が要請に応えてくれています」と 村山機構長は話す。

また、ローレンスバークレー国立研究 所（米国カリフォルニア州バークレー）の ノーベル賞天体物理学者ジョージ・スムー トは、予算の削減により「日本は信頼で きるパートナーでないとの強いメッセージ を世界に送ることになるでしょう」と語つ たことが日本のメディアで報道された。

ハワイ大学 (米国) の海洋地球物理学 者グレッグ・ムーアは、JAMSTEC が所有 する世界最大の地球深部探査船「ちき中 う」を用いた深海地球ドリリング計画に ついて、10～20\%の予算縮減が提言さ れたことを嘆いている。ムーア氏は、「技 術の至宝である『ちきゅう』の運営費を 削減し、むだに放置するような行為を、 日本政府が正当化できるとは到底思えま せん。全世界の海洋地球科学のコミュニ ティーで、統合国際深海掘削計画 (IODP) における日本の指導力に対する信頼は急 速に低下していくでしょう」とした意見書 を文部科学省に送った。

政府は、ワーキンググループの提言を 検討中で、年内に予算案を発表する予定だ。 (菊川要 訳) 